Journal of the Scholarship of Teaching and Learning, Vol. 21, No. 1, April 2021, pp. 152-170.

doi: 10.14434/josotl.v21i1.30552

\title{
Undergraduate Research Embedded Across Course Levels and Types through Scaffolded Projects
}

\author{
Sara Z. Evans \\ Kennesaw State University \\ sevan120@kennesaw.edu \\ Jocelyn Evans \\ University of West Florida
}

\begin{abstract}
This article explores how to embed an undergraduate research project within a course and summarizes the student experience in courses including undergraduate research. The authors specifically focus on how to modify and alter materials to fit with different course foci and different course levels. We have been leading an interdisciplinary, multi-year research project for the past four years. During that time, we have scaffolded a research project from year to year. Each piece of the project has been embedded within a course. However, the specific course level and content focus has changed from year to year. By embedding a research project within a class, faculty members have a unique opportunity to give their students a high-impact experience and further their own research simultaneously. We have successfully mentored and supervised students in the following formats: a freshman interdisciplinary honors course, two different undergraduate criminal justice courses made up of 5-10 students that were focused around criminological theory testing, individual directed study projects with graduate students, a 30-40 person upper level criminology research methods course, and a freshman individual directed study research project. Throughout all of these modalities, we have kept a core type of course design and course requirements but modified the components and grading criteria as needed for the type and level of course. We will summarize and discuss student assessment data both on their experience in the course as well as their achievement of student learning outcomes.
\end{abstract}

Keywords: Undergraduate research, course-based undergraduate research, and faculty professional development.

\section{Introduction}

The Council on Undergraduate Research (CUR) defines undergraduate research as "an inquiry or investigation conducted by an undergraduate student that makes an original intellectual or creative contribution to the discipline" (n.d.). Undergraduate research, scholarship, and creative activity (subsequently abbreviated as UGR) is designated as a high-impact practice (HIP) based on Kuh's original (2008) list. It has continued to be one of the most utilized and studied HIP experiences. There are three major areas of positive outcomes associated with participation in UGR. These include learning gains (either course specific or broader skills such as critical thinking) (Gray \& Phillips, 2019; Lopatto, 2007; Ishiyama \& Breuning, 2003), personal characteristics such as self-efficacy and selfesteem (Helm \& Bailey, 2013), and a greater likelihood of persisting to graduation in a timely manner and acceptance into graduate/professional school (Ishiyama \& Breuning, 2003).

While the benefits of UGR are well-documented (Brownell \& Swaner, 2010), there are many challenges associated with engaging students in a high-quality UGR experience. Faculty have finite time and resources, and UGR typically requires more than the traditional classroom experience or individual research (Beer \& Thompson, 2017). Providing a high-quality, valuable student experience 
is an important and vital part of engaging in UGR. However, faculty (especially untenured faculty) cannot ignore requirements to progress their careers through the achievement of tenure and promotion. While these two things may sometimes seem at odds, this article attests to the value of embedding undergraduate research across the curriculum and aims to provide faculty tools and strategies with which they can do both at the same time without sacrificing the quality of the experience.

Undergraduate research builds scholarly identity, improves retention, supports academic progress to degree completion, and develops soft skills that employers value. Given these benefits, institutions should encourage undergraduate research across the student academic career. Faculty engage in scholarly and creative activities within and across disciplines, and their classrooms provide valuable opportunities for including students in the research enterprise. In this piece, we report on a long-term interdisciplinary collaboration at a regional comprehensive institution involving undergraduate research across courses at different levels. Quantitative and qualitative assessment data highlight student gains and offer critical moments for reflection on best practices for faculty interested in weaving undergraduate research throughout their teaching.

\section{Literature Review}

\section{Undergraduate Research as a High-Impact Practice}

Existing scholarship on UGR highlights several dimensions of inquiry. Some researchers focus on UGR as HIP and measure the degree to which the UGR experience aligns with Kuh \& O'Donnell's (2013) essential elements of a HIP. This research generally finds that when UGR experiences include most of the essential elements, they are more successful and students report better satisfaction (Kuh \& O'Donnell, 2013). For example, surveyed students participating in UGR who reported greater effort and greater time investment from the faculty member (both essential elements) report greater benefits from the experience (Salsman, Dulaney, Chinta, Zascavage, \& Joshi, 2013).

Other studies focus on measuring the degree to which students meet desired learning outcomes that theoretically should be associated with UGR as a HIP. To measure critical thinking and communication skills, some faculty use the Association of American Colleges \& Universities (AAC\&U) VALUE rubrics for these learning outcomes (Rhodes, 2009). Campus outlets for the presentation of student posters often include an undergraduate research showcase. Gray \& Phillips (2019) present results indicating that students who engaged in UGR and presented that work were able to achieve above average skill scores for all dimensions on the VALUE rubrics. Additionally, their results show excellent interrater reliability using the rubrics, suggesting these rubrics are a promising instrument for assessing UGR (Gray \& Phillips, 2019).

While there is less longitudinal research on the benefits of HIPs, some studies do exist. Participation in HIPs in college predicts higher levels of civic engagement in adulthood, even when controlling for potential selection effects. This includes research with a faculty member (Myers, C. B., Myers, S. M., \& Peters, 2019). Additionally, the total number of HIPs a student participates in is a greater predictor of civic engagement than any one type. Lopatto (2011) used the Survey of Undergraduate Research Experiences (SURE) data to assess the impact of UGR. Results indicated that the majority of students who participated in UGR sustained or increased their interest in postgraduate education and reported the highest learning gains in "understanding of the research process in your field" (Lopatto, 2011). Taken together, these findings provide important evidence that HIPs in undergraduate education can have lasting impacts.

Finally, growing evidence suggests combining two HIPs in the same experience can have even greater impacts on learning. Combining undergraduate research with a learning community, for

Journal of the Scholarship of Teaching and Learning, Vol. 21, No. 1, April 2021. josotl.indiana.edu 
example, can enhance learning amongst first-year students (Mumford, Hill, \& Kieffer, 2017). Students benefit from the intentional design of integrating HIPs together, and the collaborative learning environment serves to facilitate deeper learning of the research content. Data on alumni-reported gains and employment/post-graduate benefits suggest that participating in UGR has a powerful impact on the pursuit of graduate education, securing employment, and perceiving learning gains such as higher-order thinking (Schmitz \& Havholm, 2015).

\section{Undergraduate Research and Progression of Academic Career}

Faculty members have many competing demands for their time and energy. The allocation of time and resources depends greatly on the workload assignment that is required by the type of institution. For most faculty, this involves some allocation of time toward teaching, research, and service. At institutions where teaching is the primary responsibility, faculty often feel that teaching and research expectations are at odds with one another (Ronnenberg \& Sadowski, 2011). This becomes even more complicated and difficult with the addition of a HIP such as UGR. Providing a high-quality experience in UGR requires more time and effort than a traditional classroom environment (Beer \& Thompson, 2017). While we recognize that this may be true, we argue that faculty can also be strategic about the way they design their courses and research projects to maximize time and energy. Embedding UGR within a course can also have benefits such as the inclusion of many more students than would be possible in a directed study format, which not only can increase the overall impact of the research experience, but it can also increase data generated from an individual project.

Many colleges and universities do not have formal policies by which to recognize excellence in UGR, especially if it happens outside the normal teaching load. Even if this work is embedded within an 'in-load' course, formal policies do not typically reflect the increased time needed for UGR compared to a typical class. Furthermore, disciplinary differences impact the degree to which this type of work is valued (Schultheis, Farrell, \& Paul, 2011). Formal recognition of UGR in tenure and promotion criteria is needed and can take many forms (Rohs, 2011; Ronnenberg \& Sadowski, 2011; Schultheis et al, 2011). While pushing for formal recognition of investment in UGR as a high-impact practice, faculty can implement other strategies to increase the impact and long-term use of the research they conduct with students, some of which are outlined and discussed next.

\section{The Role of Mentoring in Undergraduate Research}

Conducting a thorough review of the literature on undergraduate research, Linn, Palmer, Baranger, Gerard, and Stone (2015) demonstrate that mentors are crucial to the success of these high-impact experiences. Mentoring meets two significant goals when successfully implemented. Mentors help students deepen their scientific understanding as well as see themselves as emerging researchers.

Mentors ideally orient undergraduates to develop and integrate (i) conceptual knowledge and background information in the topic of the research experience; (ii) science practices such as developing an argument from evidence; and (iii) insights into the culture of the lab, including the requirements of the funding and the roles of the participants. Mentors guide students to form a scientific identity by helping them imagine roles they can play in the lab, recognize gaps in their knowledge that future courses will fill, and identify ways to contribute that also strengthen their current capabilities (Linn et al., 2015:629).

Keller, Logan, Lindwall, and Beals (2017) outline a multi-dimensional support model for mentorship developed as a diversity initiative to benefit undergraduate students from traditionally

Journal of the Scholarship of Teaching and Learning, Vol. 21, No. 1, April 2021. josotl.indiana.edu 
underrepresented backgrounds who are aspiring researchers. They identify three distinct roles for mentorship, including peer mentors, career mentors, and research mentors. Though their model pertains to the health sciences, it is easily transferable to a variety of disciplines. It only requires student peers, faculty, and research assistants in the form of lab supervisors, undergraduate student mentors, or graduate students. Keller et al. (2017) argue that the participants in this model support students holistically across the "academic, psycho-social, and research domains by virtue of their roles as faculty, peers, and researchers."

The perspectives of mentors and mentees concerning the benefits and challenges of mentoring provides valuable insight. Gunn, Lee, and Steed (2017) find that "Mentors reported the process of role modeling to be most beneficial yet challenging. Mentees reported psychological and emotional support to be most beneficial, but academic and knowledge support to be challenging". In an article that summarizes the student perspective on mentoring, Pita, Ramirez, Jaocin, Prentice, and Clark (2013) outline five essential elements that students identify are needed in a mentoring relationship, which include making yourself available, fostering community, being attentive, encouraging participation in a broader research community, and being understanding. All of these elements generally align with research conducted by scholars in this area and again come back to one of the central elements of HIPs, which is to increase high-quality student engagement.

This conforms to existing scholarship on mentoring as a first-year initiative. Institutions often structure peer-mentoring programs to support the freshman cohort because these programs are linked to student engagement and increased retention. Yomtov, Plunkett, Efrat, and Marin (2015) find that students with peer mentors "felt significantly more integrated and connected to their university at the end of their first semester compared with non-mentored students." Their results suggest that these programs help with student integration and support, which in turn reinforces retention and persistence (Yomtov et al., 2015). Honors programs often combine common curriculum in the first year with peer mentoring and living-learning opportunities to build community, improve college readiness, and grow retention.

In sum, existing scholarship on undergraduate research suggests its utility as a high-impact practice, particularly when it includes all of the essential elements of a HIP. As a HIP, undergraduate research yields significant gains for students. Done well, it improves retention and academic progress. It also enhances critical thinking, communication, and civic engagement. These are important institutional goals and student learning outcomes for undergraduate students across the curriculum. However, engaging students in UGR takes a great deal of time, effort, and resources, which can be in short supply to faculty with active research agendas. Formal and informal mentorship can help to some extent, assisting students in developing a scholarly identity and deepening their scientific understanding. It is our contention, however, that even without significant resources, faculty can adopt a pedagogical approach of scaffolding UGR throughout their course load to benefit students and advance their research agenda. We suggest that faculty can 'work smarter, not harder' when it comes to UGR.

\section{The Current Study}

The current study describes a multi-year, interdisciplinary research project that has involved multiple courses. We have embedded undergraduate research in courses across a variety of formats: a freshman interdisciplinary honors course; two different special topics courses in criminal justice made up of 515 undergraduate students focused on investigating crime and public space; multiple directed study projects with graduate students; and a 30-40 person upper-level criminology research methods course. While this project has had multiple iterations, the assessment data in this study focus specifically on two courses: one semester of a freshman level honors course, and one semester of a special topics

Journal of the Scholarship of Teaching and Learning, Vol. 21, No. 1, April 2021. josotl.indiana.edu 
criminal justice course (400 level with sophomores, juniors, and seniors). We recognize that the honors population is unique, typically drawing high-achieving students. Honors programs often suffer from a lack of diversity. However, honors curriculum provides opportunities for interdisciplinary and teambased learning through foundational experiences. It also challenges students across majors to engage in research absent any training or prior knowledge. Table 1 presents demographic characteristics of the student population participating in the freshman course used in this study to highlight the potential for embedded undergraduate research throughout the curriculum. It also provides the distribution of declared majors. In terms of the honors students, 16\% self-identified as nonwhite. An additional 5\% identified as Hispanic. Approximately $70 \%$ of the population self-identified as female. In terms of declared majors, only $8 \%$ of the class had a declared major in the social sciences - the orientation of the faculty leading the undergraduate research experience in the courses included in this study. Unfortunately, information on declared major is no longer available for the criminal justice students, but demographic information for this group is included in Table 1, as well. This group was split in half in terms of males and females and had a slightly more diverse racial/ethnic makeup, with about $33 \%$ identifying as nonwhite.

The institution at which these projects took place is a mid-sized, regional comprehensive university in the Southeast. At the time of the projects, student enrollment was about 10,000 undergraduate students. The experiences discussed in the present study attest to the benefits of a scaffolded approach to UGR. Faculty can maximize time and effort by intentionally designing research projects to be embedded within multiple courses and with various sizes of student groups. In this study, we focus on three separate courses within the overall project and examine direct and indirect measures of student learning outcomes, highlight relevant assessment instruments, and provide supportive evidence of scaffolded UGR as best practice.

\section{Pedagogical Approach of Scaffolded Undergraduate Research}

One strategy that can be utilized by faculty is to scaffold their research projects over time to work on smaller parts of a bigger research question with multiple groups of students. We encourage faculty to conceive of their broad research agenda as a funnel (see Figure 1). First, consider the 'big' question that defines the research agenda. Then, distill the question into multiple smaller research questions that could potentially be answered in the confines of one semester. By approaching a research question in this way, faculty members are able to complete meaningful sub-projects that can contribute to a larger body of results/data. Consider the types of data that could be collected and identify distinct modes of data collection to contribute to a robust data set. Finally, arrive at a single approach to addressing the research puzzle that is well-suited to examination by undergraduate students in the parameters of a course or set of courses. Assignments and assessments can also be used in multiple venues to maximize time and effort.

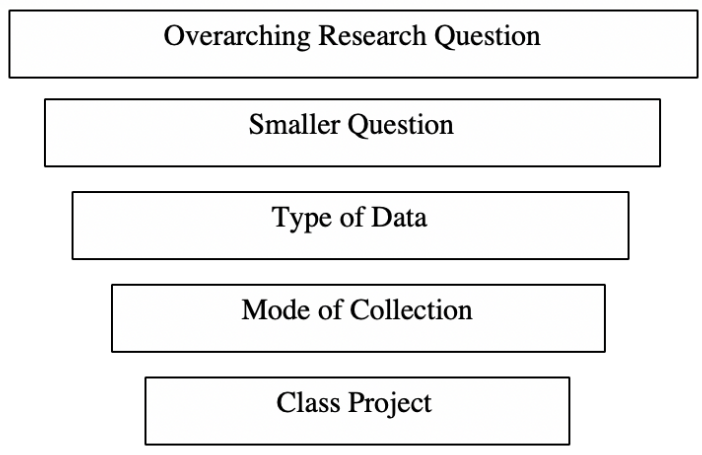

Figure 1. Conceptualizing Research Agenda for UGR.

Journal of the Scholarship of Teaching and Learning, Vol. 21, No. 1, April 2021. 


\section{Designing a Long-Term Project}

The project outlined in this article began with the question, "What is the role of public space in shaping community relationship dynamics?” We intentionally crafted a broad research question for several reasons. First, it created the ability to break off smaller research pieces that could be addressed with different groups of students. Second, it provided ample opportunity for interdisciplinary collaboration to lighten the load of student management. Figure 2 shows how this project was divided into smaller pieces. Over the course of four years, student groups of varying sizes and disciplines addressed each of these questions. For example, in the first year of the project, a large, freshman-level honors course collected observational data using standardized indices. This was most appropriate for this course level and student population. The following year, this data collection was repeated but was supplemented by a smaller group of criminal justice majors enrolled in a special topics class who collected survey data by approaching individuals face-to-face and asking them to participate in the study. We set a higher benchmark for criminal justice students in terms of both content knowledge and research methods. Additionally, we worked with individual students on directed study projects related to this overall question.

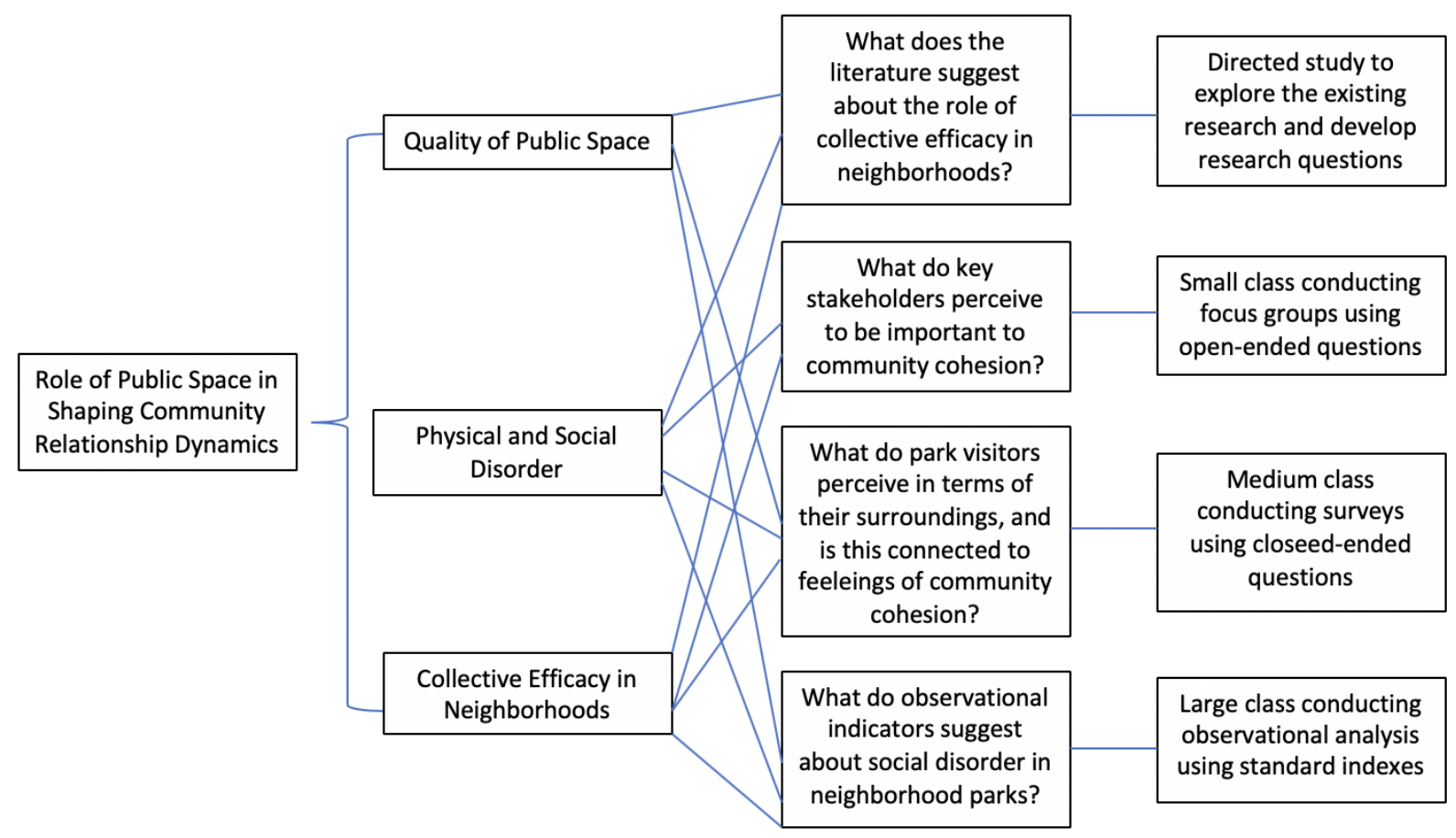

Figure 2. Interdisciplinary Research Question and Sub-Questions.

One of the most impactful aspects of this research project (especially in terms of the ability to embed a project in a course of 50+ students) is the interdisciplinary nature of the work. By bringing together multiple faculty members to work on the same project through different lenses, we generate exponentially more data with less time and effort on each individual instructor. We caution faculty members to choose their collaborators wisely, but forming a research team that is complementary in terms of disciplinary expertise and student management skills can be incredibly fruitful. Ryser, Halseth, and Thien (2009) argue that multi- and interdisciplinary teams can bring together disparate disciplinary perspectives that can fit together like a jigsaw puzzle and contribute to the whole. 
Lastly, carefully consider instruments for data collection. What instrument can multiple groups of students use in successive years to build a larger dataset? Observational and/or survey data can often be valuable even if it contains data collected at multiple time points, assuming they are obtained within a reasonable timespan. Relatedly, intentional data collection across courses can yield robust results within just a few years. Consider how to build a multifaceted dataset by targeting individual pieces with specific groups of students. For example, a small group of students could conduct focus groups one semester to refine a survey instrument and provide qualitative data. The following semester, a larger class of students could administer the survey to respondents. Future groups of students could help analyze the data to answer their own research questions. If implemented with the essential elements of HIPs included, all of these could be valuable and impactful undergraduate research experiences.

\section{Designing Course Assignments and Assessments}

Another strategy that has been particularly useful has been to design course assessments and assignments so that they may be used in multiple venues. For example, we use an index to measure student experience in our courses (adapted from Gordon, Barnes, \& Martin, 2009). Designed with a breadth of assessment of UGR in mind, the index is appropriate for administration across multiple groups of students with little modification. See Table 2 for this index, which is used to measure the impact of a criminal justice HIP outlined in Abderhalden, Snyder, and Evans (2016). This table contains results from two different courses, the results of which are discussed below.

Secondly, we utilize assignments and rubrics from our own prior courses to lessen the load of course design. Although our courses range from a freshman honors course, to a small criminal justice course, directed study students, and a criminal justice research methods course, there are many elements of assignments and rubrics that can be reused. For example, both the freshman-level honors course and the criminal justice course require a research project. Understandably, the expectations for students in these two courses are different. However, the elements that make up a 'research paper' remain largely the same. The detailed requirements for each element of the paper change. Table 2 shows one final paper rubric modified for use in various levels of courses. We use this particular example in a freshman-level honors course, but it can easily be revised for application in other contexts. Rubrics used across courses retain essential categories for assessment of research activities; the point values assigned to each of those categories vary based on the level of the course. Additionally, the detailed description of what is required for meeting and exceeding expectations varies based on the course.

A third place that assessments can be recycled to save time is in the development of reflection activities. Critical reflection is a key element of HIPs (Kuh \& O'Donnell, 2013). Allowing students the space and time to reflect and integrate their learning can have powerful impacts on their long-term learning. There are a number of existing models for critical reflection; one of the most commonly used is the DEAL model developed by Ash and Clayton (2009). Regardless of model, faculty members can utilize similar instruments for critical reflection across multiple groups of students. Linn et al. (2015) emphasize the need for critical reflection and integration of learning based on their investigation of 60 studies on UGR.

\section{Providing Mentorship Given Resource Constraints}

Although mentorship of undergraduate researchers can take substantial time and energy to do well, there are also opportunities to maximize effort in this area. As mentioned above, peer mentors can provide valuable support to lighten the load on the instructor. This could take the form of either

Journal of the Scholarship of Teaching and Learning, Vol. 21, No. 1, April 2021. josotl.indiana.edu 
upper-level undergraduate students or graduate students. These students can be an important asset in mentoring students. There are many tasks such as managing schedules, distributing documents and materials, and answering questions that graduate students are well-prepared to do but undergraduate students could also be trained to excel at. Not all faculty have the availability of paid graduate assistants, but targeting students with similar research interests (either within the faculty member's discipline or outside it) can result in productive collaborations. Graduate students who participate in mentoring undergraduates can learn valuable leadership and supervisory skills, as well as advance their own research agendas. One graduate student who supervised a group of undergraduates in a criminal justice class remarked:

The most important lesson I think I learned from this class came not from the class room or the data collection but from interacting as a graduate student with undergrads....this class was a real eye opener for me as to how to deal with other students and how sometimes a leader's expectations are not met.

This student recently completed a Ph.D. and was able to begin developing her skills as a leader early in her master's program because of participation in UGR.

The second and perhaps even more simple way that faculty can maximize effort in mentoring is to keep a file of information that is transferable across UGR experiences. To be clear, quality mentoring involves personalizing the experience for each student and each research project. However, there are many questions and issues that will likely occur repeatedly across situations. Faculty members can save time by keeping records of email responses, instructions, and even a list of 'frequently asked questions' that can be distributed to students in more than one specific project. One way to facilitate this is to create an online module that can be incorporated in multiple courses through the learning management system.

\section{Assessment Data Supporting Pedagogical Approach}

The following sections describe several types of assessment and present results from those assessments stemming from three iterations of the large-scale research project discussed in this article (one honors freshman course and two criminal justice special topics courses centered around a research project). The analysis includes results from student assessment of the experience, assessment of achievement of student learning outcomes, and critical reflection assignments. The university IRB approved the data collected for these assessments, and all students represented in these results signed informed consent documents allowing their responses to be used for research purposes.

\section{Assessment of UGR Products and Student Learning Outcomes}

The assessments we utilize for these various UGR experiences are not exactly the same. Unfortunately, the audience for course assessment varied and led to inconsistent evidence. For example, the honors course provides macro student-learning outcome data to the institution's coordinator of general education. The criminal justice courses were both funded in part by the university Quality Enhancement Plan (QEP). As a result, the QEP dictated the shape and purpose of the assessment. However, in the same way that we utilize rubrics that have been modified across different courses and can compare results of overall scores across courses, we still can provide some summary comments based on the percentage of students who met or exceeded expectations, even if the exact benchmarks reflecting the achievement of those milestones slightly differ. Given that, results are not exactly

Journal of the Scholarship of Teaching and Learning, Vol. 21, No. 1, April 2021. josotl.indiana.edu 
replicable across courses, but the assessments and assignments were similar enough to present them together.

For the upper-level criminal justice students, the primary learning outcomes involved written and oral communication. The undergraduate students completed poster presentations in groups and presented these in a public forum (graduate students also completed a research paper). The first class conducted their own poster session, which was attended by faculty and administrators from within the college. The second class participated in the university student scholar symposium. Items on the rubrics assessing oral communication skills include measures such as "uses sources that are appropriate and relevant," "language and content serve the intended purpose of the communication," and "states a clear conclusion that is consistent with the evidence presented." Evidence indicates that in both iterations of the course, over $75 \%$ of the students either met or exceeded expectations for all domains of communication skills (rubrics available upon request). Furthermore, the majority of students earned either an A or B for the course overall, indicating a successful grasp of content-based learning outcomes. This course included a variety of students with regards to experience in research, major, class year, and GPA. Given that, a high grade in this course was not necessarily expected for everyone.

The honors course meets a general education requirement. Consequently, the metrics for assessing student learning outcomes differ. Students in the honors course work in small groups to complete focused segments of the overall research project, which they presented at a panel presentation in the student scholar symposium. Given the level of the course, the main learning outcomes assessed for this class are teamwork and integration of knowledge from throughout the course. Over the course of the semester, $82 \%$ of students met or exceeded expectations for teamwork, and $80 \%$ of students met or exceeded the benchmark for synthesis of information. Furthermore, $84 \%$ of students reported that they felt work with their peers facilitated learning. Select students from all of these courses were accepted to present at the Southern Criminal Justice Association and the American Society of Criminology annual meetings.

\section{Assessment of Student Experience}

To capture an indirect measure of student learning, we utilized the assessment instrument developed by Gordon, Barnes, and Martin (2009). The instrument is on a scale from 1-4, with 1=Strongly Agree; 2=Agree; 3=Disagree; and 4=Strongly Disagree. Table 3 presents the battery included in the assessment instrument. We adapted their original rating scheme and augmented it with additional measures to capture student perceptions related to the general education learning outcomes of the freshman honors course. These items focus on interdisciplinary thinking, synthesis of information, and project management. We report these measures here because of their connection to the goals of undergraduate research as a high-impact practice.

Table 3 reveals some key findings across both student populations. One student enrolled in the upper-level criminal justice course (represented in the demographics in Table 1) elected not to complete the course assessment, and as a result, there is a discrepancy in the $\mathrm{N}$ for Tables 1 and 2. Students in both courses by and large reported a great deal of engagement with classmates and instructors. They recognized that the course required more than rote memorization of material, instead asking them to engage in active learning and direct experience. They did not find these courses to be easier than they expected them to be. Class attendance and participation, small group discussion, and instructor/student engagement (through Q\&A) were vital to success. Students did find that working with their peers to be a good way to facilitate learning. Honors students reported interdisciplinary thinking, information synthesis, and project management.

Journal of the Scholarship of Teaching and Learning, Vol. 21, No. 1, April 2021. josotl.indiana.edu 
There are some notable differences in the responses of the two student populations. The students in the upper-division criminal justice course reported learning much more from field research and hands-on research than a traditional classroom experience. They also reported learning more about themselves through the hands-on experience. The honors students did not report as many gains in these dimensions. The upper-division students also appear more likely to recommend the experience to a friend. Perhaps some of this variance is attributable to the selective nature of the honors program, as well as the limited access of this cohort-based course.

\section{Critical Reflection Results}

The final essential type of assessment is critical reflection. In each of the iterations of this research project, students engaged in critical reflection. Students reflected on their experience after their first time in the field and then again after subsequent trips. Lastly, the end of semester feedback includes some form of reflection. For the upper level criminal justice courses, this involves a reflection paper; for the lower-level honors course, this takes the form of short responses about the experience. While not all students report enjoying the research part of the course, many have positive things to say. Please note that these reflection quotes are taken from these two different course experiences, so the implications of them differ, but we specify what level of student reported each. One freshman honors student remarked, "I liked the learning experience that the field experience had to offer and how I had to overcome different obstacles and realize that some things just don't work out like you think they should." We stress for all students that flexibility is important. Students often are surprised by the challenges encountered during data collection. In a final reflection paper, one of the upper-level criminal justice students said, "Overall from this class and from data collection I have learned a lot. I learned how to be a better researcher and how to apply classroom knowledge to actual hands on application."

In addition to benefits associated with content knowledge and research skills, several students commented that they were able to enhance personal characteristics such as confidence in interacting with strangers, as indicated by this criminal justice student's comment:

The biggest impact in my personal learning experience was the direct interaction with the campers as I was forced out of my shell (so to speak) and I gained valuable experience with dealing with them and with approaching them which has been the recurring most difficult part of interacting with strangers in my case. This is going to be extremely helpful not only in my career, but also in my day-to-day interactions and experiences with people...

A number of other students had similar remarks, indicating that they not only increased their knowledge and skills related to research, but they also developed broader transferable skills.

\section{Discussion}

Results from the current study provide further corroboration and support for existing literature on UGR as a HIP. Over the course of several years and with different levels of students, we consistently demonstrated benefits such as increased communication skills, teamwork, and content-based learning outcomes. There were some differences in the learning gains based on student population. For example, upper-level criminal justice majors reported that the field work they conducted was more meaningful to their learning than the time they spent in a traditional classroom. This is likely due to differences in data collection methodology and the level of students in each class. The criminal justice students administered surveys on multiple days for long stretches under the constant supervision of

Journal of the Scholarship of Teaching and Learning, Vol. 21, No. 1, April 2021. josotl.indiana.edu 
instructors. There were ample opportunities both in the field and in the classroom to talk about the research project and reflect on the value of the experience. The freshman honors students were given some of these same opportunities, but their course was not solely focused on the research project. Some students collected survey data while others collected observational data. As a result, some students never interacted with human subjects in the field. Additionally, data collection was done over shorter periods of time in small groups rather than by the whole class synchronously. Furthermore, students sharing a declared major and several program requirements most likely would be more prepared for real-world application of content than freshman from different majors in an interdisciplinary course satisfying a general education and honors requirement.

Based on the results of this collaboration, faculty considering long-term collaborative research projects involving undergraduate students should set appropriate expectations for gains in learning outcomes relative to class size, student population, and diversity of majors. Faculty should consider the degree to which supervision, reflection, and synthesis are linked to student gains. Formal or informal peer mentoring and interdisciplinary partnerships might help faculty achieve the benefits of undergraduate research as a high-impact practice in situations where institutional or departmental resources are scarce.

The second goal of this article was to provide suggestions that faculty members can implement in their own teaching and research to maximize time and effort. Forethought and early planning can lead to a high-quality experience for the students involved and a better, more valuable research product for faculty members. The projects outlined here and other related interdisciplinary UGR projects have resulted in four peer-reviewed publications, approximately 60 research posters (one of which won second place at the university symposium and one of which won best student poster at a regional criminal justice conference), two full thematic panel presentations at a national conference, and a grant proposal to a national funding agency. Additionally, there are at least seven students so far that credit their participation in this project as being integral to the decision to attend graduate school. One of those students recently completed a Ph.D. These results emphasize the point that economizing time and energy does not imply compromising quality or lowering expectations. With adequate planning, both can be achieved simultaneously.

While the projects outlined here have been largely successful, there are limitations that we hope to address in future research. First, the assessment was not a double-blind assessment of work, and we acknowledge the potential introduction of bias. Given the nature of the assessments as course assignments (including some oral presentations), it was not possible for the instructors to conduct assessments of student work without knowing their identities. Second, it is possible that some higherperforming students self-selected themselves into these experiences, and a portion of the successful outcome could be attributed to this phenomenon. However, as we discussed above, we had a variety of students represented in both courses. Lastly, we had the benefit of including several graduate students to assist in mentoring students through some of these projects, and we acknowledge that this is not an option for many faculty members at teaching-focused institutions. We encourage faculty members to also consider inviting upper-level undergraduate students to serve as peer mentors as another option.

\section{Conclusions and Implications}

While assessment tools and results from one large project are presented here, there is room for improvement in several areas. Perhaps most importantly, there is a need for more consistency in assessment of UGR as a HIP to validate the benefits outlined here and in other studies. Most claims about the impact of UGR are largely based on self-reports from students, and many lack standardized assessment or assessment of learning gains based on research products (Linn et al. 2015). The

Journal of the Scholarship of Teaching and Learning, Vol. 21, No. 1, April 2021. josotl.indiana.edu 
scholarship on assessment in HIPs offers potential scales by which to measure self-efficacy and scientific literacy (Sams et al., 2015). Additionally, a recent article by Finley (2019) lays out a comprehensive plan for assessing HIPs. In the future, we plan to utilize validated assessments to further add to this body of research.

Great need exists for systematic and programmatic changes to increase participation in undergraduate research. In a study of one psychology department with approximately 550 majors and 21 faculty members, Wayment and Dickson (2008) underscore this need. Barriers to participation in UGR include lack of awareness of opportunity, lack of a formalized system to involve students, poor timing in curriculum, no outlet for dissemination, and uneven compensation for faculty who supervise UGR. Implementation of structured changes to address each of these barriers led to significant and substantial increases in UGR participation (Wayment \& Dickson, 2008). Changing policy and departmental bylaws are both effective and important ways to ensure recognition for UGR, but this is not always possible given particular climates at the departmental/college/university levels. For this reason, we intentionally provide strategies that do not rely on large-scale policy changes.

It is important to recognize the difference in class size across our student populations. The directed studies and upper-division courses were smaller than the freshman honors course. It might be that students in larger courses see less relative value in the undergraduate research experience compared to students in capped upper-division courses. Freshmen taking general education requirements often are in courses outside of their majors and bring fewer course experiences by which to compare the activity.

Students come to the classroom from diverse backgrounds. Engaging freshmen in highimpact, hands-on research activities promote retention and progress towards degree completion. It helps these students develop their identity as research scholars. It might be, however, that more advanced students recognize the added value of these experiences more readily. They have more coursework by which to compare the structural differences in the pedagogical approach and the opportunity for real-world application and skill development. This article outlines strategies by which faculty members can more efficiently and effectively scaffold their undergraduate research projects across multiple venues with different student groups. We suggest that with intentional planning, a faculty member can save time and resources while still designing a high-impact experience for students and generating high-quality data.

\section{Acknowledgments}

The authors would like to thank Dr. Jamie Snyder and Dr. John D. Morgan for their contributions in the early stages of this work. We would also like to thank Dr. Frances Abderhalden for her tireless work as an undergraduate and graduate student. 


\section{Appendix}

Appendix 1. Table 1. Demographic Characteristics of Student Populations.

\begin{tabular}{|l|l|l|l|l|}
\hline & \multicolumn{3}{|l|}{ Honors (n=60) } & \multicolumn{2}{l|}{ CJ (n=12) } \\
\hline & Percent & $\mathrm{N}$ & Percent & $\mathrm{N}$ \\
\hline Gender & & & & \\
\hline Male & $29 \%$ & 18 & $50 \%$ & 6 \\
\hline Female & $71 \%$ & 44 & $50 \%$ & 6 \\
\hline & & & & \\
\hline Race & & & & \\
\hline Black & $8.1 \%$ & 5 & $8.3 \%$ & 1 \\
\hline Asian & $3.2 \%$ & 2 & $16.7 \%$ & 2 \\
\hline Pacific Islander & $1.6 \%$ & 1 & $0 \%$ & 0 \\
\hline White & $83.9 \%$ & 52 & $66.7 \%$ & 8 \\
\hline & & & & \\
\hline & & & & \\
\hline Ethnicity & & & & \\
\hline Hispanic & $4.8 \%$ & 3 & $8.3 \%$ & 1 \\
\hline Non Hispanic & $95.2 \%$ & 59 & $91.7 \%$ & 11 \\
\hline & & & & \\
\hline Declared Major & & & $* * * *$ & \\
\hline AA & $1.6 \%$ & 1 & & \\
\hline Arts & $8.1 \%$ & 5 & & \\
\hline Business & $8.1 \%$ & 5 & & \\
\hline Humanities & $4.8 \%$ & 3 & & \\
\hline Mathematical Science & $11.3 \%$ & 7 & & \\
\hline Natural/Health Science & $45.2 \%$ & 28 & & \\
\hline Professional & $4.8 \%$ & 3 & & \\
\hline Social Science & $8.1 \%$ & 5 & & \\
\hline Undecided & $8.1 \%$ & 5 & & \\
\hline
\end{tabular}




\section{Appendix 2. Table 2. Example Research Paper Rubric.}

Research Paper Rubric Name:

Date:

Score:

\begin{tabular}{|c|c|c|c|c|c|c|}
\hline Category & Exceeds Standard & Meets Standard & Nearly Meets Standard & Does Not Meet Standard & $\begin{array}{l}\text { No } \\
\text { Evidence }\end{array}$ & Score \\
\hline Research question & $\begin{array}{l}\text { Clearly and concisely states } \\
\text { the paper's research question } \\
\text { in a single sentence, which is } \\
\text { engaging, and thought } \\
\text { provoking. (5) }\end{array}$ & $\begin{array}{l}\text { Clearly states the paper's } \\
\text { research question in a single } \\
\text { sentence. (4) }\end{array}$ & $\begin{array}{l}\text { States the paper's research } \\
\text { question in a single sentence. } \\
\text { (3) }\end{array}$ & $\begin{array}{l}\text { Incomplete and/or unfocused. } \\
\text { (1) }\end{array}$ & $\begin{array}{l}\text { Absent, } \\
\text { no } \\
\text { evidence } \\
(0)\end{array}$ & \\
\hline Introduction & $\begin{array}{l}\text { The introduction is engaging, } \\
\text { states the main topic and } \\
\text { previews the structure of the } \\
\text { paper. (5) }\end{array}$ & $\begin{array}{l}\text { The introduction states the } \\
\text { main topic and previews the } \\
\text { structure of the paper. (4) }\end{array}$ & $\begin{array}{l}\text { The introduction states the } \\
\text { main topic but does not } \\
\text { adequately preview the } \\
\text { structure of the paper. (3) }\end{array}$ & $\begin{array}{l}\text { There is no clear introduction } \\
\text { or main topic and the structure } \\
\text { of the paper is missing. (1) }\end{array}$ & $\begin{array}{l}\text { Absent, } \\
\text { no } \\
\text { evidence } \\
(0)\end{array}$ & \\
\hline $\begin{array}{l}\text { Organization- } \\
\text { Structural } \\
\text { Development of } \\
\text { the Idea }\end{array}$ & $\begin{array}{l}\text { Writer demonstrates logical } \\
\text { and subtle sequencing of ideas } \\
\text { through well-developed } \\
\text { paragraphs with main ideas; } \\
\text { transitions are used to enhance } \\
\text { organization. (5) }\end{array}$ & $\begin{array}{l}\text { Paragraph. dexelooment } \\
\text { present but not perfected. } \\
\text { (4) }\end{array}$ & $\begin{array}{l}\text { Logical organization: } \\
\text { organization of ideas not fully } \\
\text { developed. (3) }\end{array}$ & $\begin{array}{l}\text { No evidence of structure or } \\
\text { organization. (1) }\end{array}$ & $\begin{array}{l}\text { Not } \\
\text { applicable } \\
(0)\end{array}$ & \\
\hline Grammar & $\begin{array}{l}\text { No errors in punctuation, } \\
\text { capitalization, spelling, } \\
\text { sentence structure, or word } \\
\text { usage. (10) }\end{array}$ & $\begin{array}{l}\text { Almost no errors in } \\
\text { punctuation, capitalization, } \\
\text { spelling, sentence structure, } \\
\text { or word usage. (7) }\end{array}$ & $\begin{array}{l}\text { Many errors in punctuation, } \\
\text { capitalization, spelling, } \\
\text { sentence structure, or word } \\
\text { usage. (3) }\end{array}$ & $\begin{array}{l}\text { Numerous and distracting } \\
\text { errors punctuation, } \\
\text { capitalization, spelling, } \\
\text { sentence structure, or word } \\
\text { usage. (1) }\end{array}$ & $\begin{array}{l}\text { Not } \\
\text { applicable } \\
(0)\end{array}$ & \\
\hline Citation & $\begin{array}{l}\text { All cited works, both text and } \\
\text { visual, are done in the correct } \\
\text { format with no errors. (5) }\end{array}$ & $\begin{array}{l}\text { Some cited works, both text } \\
\text { and visual, are done in the } \\
\text { correct format. } \\
\text { Inconsistencies evident. (4) }\end{array}$ & $\begin{array}{l}\text { Few cited works, both text } \\
\text { and visual, are done in the } \\
\text { correct format. (3) }\end{array}$ & Absent (1) & $\begin{array}{l}\text { Not } \\
\text { applicable } \\
(0)\end{array}$ & \\
\hline Bibliography & $\begin{array}{l}\text { Done in the correct format } \\
\text { with no errors. Includes more } \\
\text { than } 5 \text { major references (e.g. } \\
\text { science journal articles, } \\
\text { books, but no more than two } \\
\text { internet sites. Periodicals } \\
\text { available on-line are not } \\
\text { considered internet sites) (5) }\end{array}$ & $\begin{array}{l}\text { Done in the correct format } \\
\text { with few errors. . Includes } 5 \\
\text { major references (e.g. science } \\
\text { journal articles, books, but no } \\
\text { more than two internet sites. } \\
\text { Periodicals available on-line } \\
\text { are not considered internet). } \\
\text { (4) }\end{array}$ & $\begin{array}{l}\text { Done in the correct format } \\
\text { with some errors. Includes } 4 \\
\text { major references (e.g. science } \\
\text { journal articles, books, but no } \\
\text { more than two internet sites. } \\
\text { Periodicals available on-line } \\
\text { are not considered internet). } \\
\text { (3) }\end{array}$ & $\begin{array}{l}\text { Done in the correct format } \\
\text { with many errors. Includes } 3 \\
\text { major references (e.g. science } \\
\text { journal articles, books, but no } \\
\text { more than two internet sites. } \\
\text { Periodicals available on-line } \\
\text { are not considered internet } \\
\text { sites.) (1) }\end{array}$ & $\begin{array}{l}\text { Absent or } \\
\text { the only } \\
\text { sites are } \\
\text { internet } \\
\text { sites. (0) }\end{array}$ & \\
\hline
\end{tabular}


Table 2 (cont'd).

\begin{tabular}{|c|c|c|c|c|c|c|}
\hline & Exceeds Standard & Meets Standard & Nearly Meets Standard & Does Not Meet Standard & $\begin{array}{c}\text { No } \\
\text { Evidence } \\
\end{array}$ & Score \\
\hline $\begin{array}{l}\text { Literature } \\
\text { Review }\end{array}$ & $\begin{array}{l}\text { Uses multiple sources of } \\
\text { scholarship to support } \\
\text { attention to research question. } \\
\text { Development is clear, logical, } \\
\text { and organized. }\end{array}$ & $\begin{array}{l}\text { Uses multiple sources of } \\
\text { scholarship to support } \\
\text { attention to research } \\
\text { question. Development } \\
\text { could be improved. }\end{array}$ & $\begin{array}{l}\text { Uses multiple sources of } \\
\text { scholarship, but less clear } \\
\text { how these sources support } \\
\text { attention to research question. }\end{array}$ & $\begin{array}{l}\text { Uses limited sources of } \\
\text { scholarship but lacks } \\
\text { clarity concerning how } \\
\text { these sources support } \\
\text { attention to research }\end{array}$ & $\begin{array}{l}\text { No sources of } \\
\text { scholarship } \\
\text { used to support } \\
\text { research } \\
\text { question. }\end{array}$ & $/ 10$ \\
\hline $\begin{array}{l}\text { Data and/or } \\
\text { Sources of } \\
\text { Evidence }\end{array}$ & $\begin{array}{l}\text { Lists all data } \\
\text { sources in discrete } \\
\text { section of paper. } \\
\text { Indicates variables } \\
\text { and coding. }\end{array}$ & $\begin{array}{l}\text { List some data sources in } \\
\text { discrete section of paper. } \\
\text { Indicates variables and } \\
\text { coding. }\end{array}$ & $\begin{array}{l}\text { Has data section, but the } \\
\text { section is not clear. No } \\
\text { indication of variables and } \\
\text { coding. }\end{array}$ & $\begin{array}{l}\text { Data mentioned at times } \\
\text { but not in a discrete } \\
\text { section devoted to data. } \\
\text { No indication of variables } \\
\text { and coding. }\end{array}$ & $\begin{array}{l}\text { No mention of } \\
\text { data and/or } \\
\text { sources of } \\
\text { evidence. }\end{array}$ & $/ 7$ \\
\hline $\begin{array}{l}\text { Method of } \\
\text { Inquiry }\end{array}$ & $\begin{array}{l}\text { Lists all methods of } \\
\text { inquiry in a detailed, } \\
\text { sequential order that are } \\
\text { easily followed. }\end{array}$ & $\begin{array}{l}\text { Lists all methods of } \\
\text { inquiry in a sequential } \\
\text { order, but is difficult to } \\
\text { follow. }\end{array}$ & $\begin{array}{l}\text { Lists all methods of } \\
\text { inquiry but not clearly } \\
\text { sequential and not easily } \\
\text { followed. }\end{array}$ & $\begin{array}{l}\text { Lists some method of inquiry } \\
\text { but not sequential, not easily } \\
\text { followed, or incomplete. }\end{array}$ & $\begin{array}{l}\text { Does not list } \\
\text { method of } \\
\text { inquiry. }\end{array}$ & $/ 3$ \\
\hline $\begin{array}{l}\text { Results or } \\
\text { Findings }\end{array}$ & $\begin{array}{l}\text { Analysis is organized in a } \\
\text { clear manner. All } \\
\text { illustrations are provided } \\
\text { and clear. }\end{array}$ & $\begin{array}{l}\text { Analysis is organized in a } \\
\text { clear manner with few } \\
\text { errors. All illustrations are } \\
\text { provided and clear with few } \\
\text { errors. }\end{array}$ & $\begin{array}{l}\text { Analysis is organized but } \\
\text { not clear and with } \\
\text { errors. All illustrations are } \\
\text { provided but not clear and } \\
\text { with errors. }\end{array}$ & $\begin{array}{l}\text { Analysis is provided but not } \\
\text { clear and with major errors. } \\
\text { All illustrations are } \\
\text { provided but not clear and } \\
\text { with major errors. }\end{array}$ & $\begin{array}{l}\text { No analysis } \\
\text { and no } \\
\text { illustrations } \\
\text { provided. }\end{array}$ & $/ 20$ \\
\hline $\begin{array}{l}\text { Conclusion } \\
\text { or Discussion }\end{array}$ & $\begin{array}{l}\text { Engaging and restates the } \\
\text { research question and } \\
\text { answers it for the reader. }\end{array}$ & $\begin{array}{l}\text { Restates the research } \\
\text { question in the conclusion. }\end{array}$ & $\begin{array}{l}\text { Answers the question in the } \\
\text { conclusion but does not restate } \\
\text { the research question. }\end{array}$ & $\begin{array}{l}\text { Does not address the question or } \\
\text { the answer to it in the conclusion. }\end{array}$ & $\begin{array}{l}\text { No conclusion } \\
\text { or discussion. }\end{array}$ & $/ 10$ \\
\hline Implications & $\begin{array}{l}\text { Draws clear and accurate } \\
\text { implications of work for key } \\
\text { audiences. }\end{array}$ & $\begin{array}{l}\text { Draws implications of work } \\
\text { for key audiences but less } \\
\text { clear and inaccurate. }\end{array}$ & $\begin{array}{l}\text { Draws implications of work } \\
\text { but not with key audiences in } \\
\text { mind and lacks clarity and } \\
\text { accuracy. }\end{array}$ & $\begin{array}{l}\text { Limited attention to implications } \\
\text { of work. }\end{array}$ & $\begin{array}{l}\text { No } \\
\text { implications } \\
\text { provided. }\end{array}$ & $/ 10$ \\
\hline
\end{tabular}




\section{Appendix 3. Table 3. Quantitative Feedback from CJ Course $(\mathbf{N}=11)$; Honors Core 2} $(\mathbf{N}=63)$.

\begin{tabular}{|c|c|c|c|c|c|c|}
\hline \multirow[b]{2}{*}{ Question } & \multicolumn{3}{|c|}{ Criminal Justice } & \multicolumn{3}{|l|}{ Honors } \\
\hline & $\begin{array}{l}\text { Mean (std. } \\
\text { dev.) }\end{array}$ & Min & Max & $\begin{array}{l}\text { Mean } \\
\text { (std. dev.) }\end{array}$ & Min & Max \\
\hline $\begin{array}{l}\text { My level of anxiety for this class was } \\
\text { low before beginning. }\end{array}$ & $2.45(1.04)$ & 1 & 4 & $2.22(.924)$ & 1 & 4 \\
\hline $\begin{array}{l}\text { I had little interaction with my } \\
\text { classmates. }\end{array}$ & $3.63(.67)$ & 2 & 4 & $3.21(.901)$ & 1 & 4 \\
\hline I came to class prepared. & $1.54(.52)$ & 1 & 2 & $1.89(.764)$ & 1 & 3 \\
\hline $\begin{array}{l}\text { I had little interaction with my } \\
\text { instructor. }\end{array}$ & $3.55(.69)$ & 2 & 4 & $2.87(1.008)$ & 1 & 4 \\
\hline $\begin{array}{l}\text { The class was as easy as I expected it } \\
\text { to be. }\end{array}$ & $2.73(.65)$ & 2 & 4 & $2.89(.785)$ & 1 & 4 \\
\hline $\begin{array}{l}\text { Memorization of the material is all I } \\
\text { needed to do in order to do well in } \\
\text { this class. }\end{array}$ & $3.63(.67)$ & 2 & 4 & $2.98(.871)$ & 1 & 4 \\
\hline $\begin{array}{l}\text { This course allowed me to engage in } \\
\text { activities, problems, and tasks. }\end{array}$ & $1.09(.30)$ & 1 & 2 & $1.62(.658)$ & 1 & 3 \\
\hline $\begin{array}{l}\text { I learned through direct experience in } \\
\text { this class. }\end{array}$ & $1.09(.30)$ & 1 & 2 & $1.84(.865)$ & 1 & 4 \\
\hline $\begin{array}{l}\text { I had to think about problems from } \\
\text { different academic disciplinary } \\
\text { perspectives. }\end{array}$ & & & & $1.59(.816)$ & 1 & 4 \\
\hline $\begin{array}{l}\text { Information from multiple academic } \\
\text { disciplines improved my } \\
\text { understanding of complex problems. }\end{array}$ & & & & $1.83(.890)$ & 1 & 4 \\
\hline $\begin{array}{l}\text { I had to evaluate course readings in } \\
\text { terms of the context in which they } \\
\text { were created. }\end{array}$ & & & & $1.78(.750)$ & 1 & 4 \\
\hline $\begin{array}{l}\text { I had to synthesize information from } \\
\text { divergent sources and viewpoints and } \\
\text { draw reasonable conclusions. }\end{array}$ & & & & $1.67(.648)$ & 1 & 3 \\
\hline $\begin{array}{l}\text { I had to exhibit disciplined work } \\
\text { habits as an individual. }\end{array}$ & & & & $1.65(.744)$ & 1 & 4 \\
\hline $\begin{array}{l}\text { I had to conceive, plan, and execute a } \\
\text { group service project. }\end{array}$ & & & & $1.44(.667)$ & 1 & 4 \\
\hline $\begin{array}{l}\text { Working with my peers was a good } \\
\text { way to facilitate learning. }\end{array}$ & $1.18(.40)$ & 1 & 2 & $1.70(.854)$ & 1 & 4 \\
\hline $\begin{array}{l}\text { My sense of community was } \\
\text { enhanced. }\end{array}$ & $1.18(.52)$ & 1 & 2 & $1.79(.936)$ & 1 & 4 \\
\hline $\begin{array}{l}\text { I worked with students outside the } \\
\text { classroom to enhance my learning. }\end{array}$ & $1.55(.52)$ & 1 & 2 & $1.70(.835)$ & 1 & 4 \\
\hline $\begin{array}{l}\text { I discussed the course material with } \\
\text { others outside the class. }\end{array}$ & $1.73(.65)$ & 1 & 2 & $1.63(.848)$ & 1 & 4 \\
\hline $\begin{array}{l}\text { Attending class was important for } \\
\text { learning. }\end{array}$ & $1.18(.40)$ & 1 & 2 & $1.51(.780)$ & 1 & 4 \\
\hline & Criminal Justi & & & Honors & & \\
\hline
\end{tabular}

Journal of the Scholarship of Teaching and Learning, Vol. 21, No. 1, April 2021. josotl.indiana.edu 


\begin{tabular}{|l|l|l|l|l|l|l|} 
Question & $\begin{array}{l}\text { Mean (std. } \\
\text { dev.) }\end{array}$ & Min & Max & $\begin{array}{l}\text { Mean } \\
\text { (std. dev.) }\end{array}$ & Min & Max \\
\hline $\begin{array}{l}\text { Participating in class was important } \\
\text { for learning. }\end{array}$ & $1.27(.47)$ & 1 & 2 & $1.97(.967)$ & 1 & 4 \\
\hline $\begin{array}{l}\text { Small group discussions in class were } \\
\text { important for learning. }\end{array}$ & $1.55(.52)$ & 1 & 2 & $1.90(.928)$ & 1 & 4 \\
\hline $\begin{array}{l}\text { Asking questions of instructors was } \\
\text { important for learning. }\end{array}$ & $1.36(.50)$ & 1 & 2 & $1.63(.809)$ & 1 & 4 \\
\hline $\begin{array}{l}\text { Asking questions of peer students } \\
\text { was important for learning. }\end{array}$ & $1.27(.47)$ & 1 & 2 & $1.79(.883)$ & 1 & 4 \\
\hline $\begin{array}{l}\text { I learned more in this class doing field } \\
\text { research than in a traditional } \\
\text { classroom. }\end{array}$ & $1.27(.65)$ & 1 & 3 & $2.22(.991)$ & 1 & 4 \\
\hline $\begin{array}{l}\text { This experience taught me more than } \\
\text { books or lectures. }\end{array}$ & $1.27(.47)$ & 1 & 2 & $2.03(.999)$ & 1 & 4 \\
\hline $\begin{array}{l}\text { Through hands on experience I } \\
\text { learned more about myself. }\end{array}$ & $1.45(.52)$ & 1 & 2 & $2.22(1.054)$ & 1 & 4 \\
\hline $\begin{array}{l}\text { I would recommend this class to a } \\
\text { friend. }\end{array}$ & $1.09(.30)$ & 1 & 2 & $2.21(1.080)$ & 1 & 4 \\
\hline $\begin{array}{l}\text { I would take another class like this } \\
\text { one with hands on learning. }\end{array}$ & $1.27(.47)$ & 1 & 2 & $1.92(.903)$ & 1 & 4 \\
\hline *Adapted from Gordon, Barnes, \& Martin, 2009 & & & & & \\
\hline \begin{tabular}{l} 
questions were not included in CJ assessment \\
\hline
\end{tabular}
\end{tabular}

\section{References}

Abderhalden, F., Snyder, J. A., \& Evans, S. Z. (2016). Creating the code of the campground: Developing high impact experiences in criminal justice. Journal of Criminal Justice Education, 27(3), 410-431. https://doi.org/10.1080/10511253.2016.1144990.

Ash, S. L., \& Clayton, P. H. (2009). Generating, deepening, and documenting learning: The power of critical reflection in applied learning. Journal of Applied Learning in Higher Education, 1(1), 25-48. https://scholarworks.iupui.edu/handle/1805/4579.

Beer, F., \& Thompson, J. (2017). Undergraduate and graduate research and creative activities: Faculty's evaluation, time commitment, and perceived barriers. A practice report. Student Success, 8(1), 73-78. https://doi.org/10.5204/ssj.v8i1.329.

Brownell, J. E., \& Swaner, L. E. (2010). Five high impact practices: Research on learning outcomes, completion, and quality. Washington, DC: Association of American Colleges and Universities.

Council on Undergraduate Research. (n.d.). Mission statement. Retrieved from https://www.cur.org/who/organization/mission/

Finley, A. (2019). A comprehensive approach to assessment of high-impact practices (Occasional Paper No. 41). Urbana, IL: University of Illinois and Indiana University, National Institute for Learning Outcomes Assessment (NILOA).

Gordon, J. A., Barnes, C. M., \& Martin, K. J. (2009). Undergraduate research methods: Does size matter? A look at the attitudes and outcomes of students in a hybrid class format versus a 
traditional class format. Journal of Criminal Justice Education, 20(3), 238-239.

https://doi.org/10.1080/10511250903200493.

Gunn, F., Lee, S. H., \& Madelyn S. (2017). Student perceptions of benefits and challenges of peer mentoring programs: Divergent perspectives from mentors and mentees. Marketing Education Review, 27(1), 15-26. https://doi.org/10.1080/10528008.2016.1255560.

Helm, H. W., \& Bailey, K. G. D. (2013). Perceived benefits of presenting undergraduate research at a professional conference. North American Journal of Psychology, 15(3).

https://digitalcommons.andrews.edu/behavioral-pubs/63.

Ishiyama, J., \& Breuning, M. (2003). Does participation in undergraduate research affect political science students? Politics \& Policy, 31(1), 163-180. https://doi.org/10.1111/i.17471346.2003.tb00892.x.

Keller, T. E., Logan, K., Lindwall, J., \& Beals, C. (2017). Peer mentoring for undergraduates in a research-focused diversity initiative. Metropolitan universities, 28(3), 50. DOI: 10.18060/21542.

Kuh, G. D. (2008). High-impact educational practices: What they are, who has access to them, and why they matter. Washington, DC: Association of American Colleges and Universities.

Kuh, G. D., \& O’Donnell, K. with case studies by Sally Reed. (2013). Ensuring quality and taking highimpact practices to scale. Washington, D.C.: Association of American Colleges \& Universities.

Linn, M. C., Palmer, E., Baranger, A., Gerard, E., \& Stone, E. (2015). Undergraduate research experiences: Impacts and opportunities. Science, 347(6222). DOI: 10.1126/science.1261757.

Lopatto, D. (2007). Undergraduate research experiences support science career decisions and active learning. CBE - Life Sciences Education, 6(4), 251-360. https://doi.org/10.1187/cbe.07-06$\underline{0039}$.

Rhodes, T. (2009). Assessing outcomes and improving achievement: Tips and tools for using the rubrics. Washington, DC: Association of American Colleges and Universities.

Mumford, K., Hill, S., \& Kieffer, L. Utilizing undergraduate research to enhance integrative learning. CUR Quarterly, 37(4), 28-32. https://go.gale.com/ps/anonymous?id=GALE\%7CA504564024\&sid=googleScholar\&v=2. 1 \&it $=\mathrm{r} \&$ linkaccess $=$ abs\&issn $=10725830 \& \mathrm{p}=\mathrm{AONE \& sw}=\mathrm{w}$.

Myers, C. B., Myers, S. M., \& Peters, M. (2019). The longitudinal connections between undergraduate high impact curriculum practices and civic engagement in adulthood. Research in Higher Education, 60, 83-110. DOI:10.1007/s11162-018-9504-4.

Pita, M., Ramirez, C., Jaocin, N., Prentice, S., \& Clarke, C. (2013). Five effective strategies for mentoring undergraduates: Students' perspectives. CUR Quarterly, 33(3), 11-15. https://go.gale.com/ps/anonymous?id=GALE\%7CA324399339\&sid=googleScholar\&v=2. 1 \&it $=\mathrm{r} \&$ linkaccess $=\mathrm{abs} \& \mathrm{ssn}=10725830 \& \mathrm{p}=\mathrm{AONE \& sw}=\mathrm{w}$.

Rohs, C. R. (2011). Undergraduate research and the tenure and promotion process. CUR Quarterly, 31(4), 13-18.

https://go.gale.com/ps/anonymous?id=GALE\%7CA265098879\&sid=googleScholar\&v=2. $1 \&$ it $=$ r\&linkaccess $=$ abs\&issn $=10725830 \& p=A O N E \& s w=w$.

Ronnenberg, S. C., \& Sadowski, J. (2011). Recognizing undergraduate research in criteria for faculty promotion and tenure. CUR Quarterly, 31(4), 10-12.

https://go.gale.com/ps/anonymous?id=GALE\%7CA265098878\&sid=googleScholar\&v=2. $1 \& i t=r \&$ linkaccess $=$ abs\&issn $=10725830 \& p=A O N E \& s w=w$.

Ryser, L., Halseth, G., \& Thien, D. (2009). Strategies and intervening factors influencing student social interaction and experiential learning in interdisciplinary teams. Research in Higher Education, 50(3), 248-267. DOI: 10.1007/s11162-008-9118-3.

Salsman, N., Dulaney, C., Chinta, R., Zascavage, V., \& Joshi, H. (2013). Student effort in and perceived benefits from undergraduate research. College Student Journal, 47(1), 202-211.

Journal of the Scholarship of Teaching and Learning, Vol. 21, No. 1, April 2021.

josotl.indiana.edu 
https://www.ingentaconnect.com/content/prin/csj/2013/00000047/00000001/art00021\# expand/collapse.

Schmiz, H. J., \& Havholm, K. (2015). Undergraduate research and alumni: Perspectives on learning gains and post-graduation benefits. CUR Quarterly, 35(3), 15-22.

https://go.gale.com/ps/anonymous?id=GALE\%7CA465166022\&sid=googleScholar\&v=2. $1 \& i t=r \&$ linkaccess $=$ abs\&issn $=10725830 \& p=A O N E \& s w=w$.

Schultheis, A. S., Farrell, T. M., \& Paul, E. L. (2011). Promoting undergraduate research through revising tenure and promotion policy. CUR Quarterly, 31(4), 25-31.

https://go.gale.com/ps/anonymous?id=GALE\%7CA265098881\&sid=googleScholar\&v=2. 1 \&it $=$ r\&linkaccess $=$ abs\&issn $=10725830 \& p=A O N E \& s w=w$.

Wayment, H. A., \& Dickson, K. L. (2008). Increasing student participation in undergraduate research benefits students, faculty, and department. Teaching of Psychology, 35, 194-197. https://doi.org/10.1080\%2F00986280802189213.

Yomtov, D., Plunkett, S. W., Efrat, R., \& Marin, A. G. (2017). Can peer mentors improve first-year experiences of university students? Journal of College Student Retention: Research, Theory \& Practice, 19(1), 25-44. https://doi.org/10.1177\%2F1521025115611398. 